\author{
(c) $(7)$ (8) \\ Jurnal Terapan Manajemen dan Bisnis is licensed under \\ A Creative Commons Attribution-Non_Commercial 4.0 International License.
}

\title{
HANDICRAFTS FROM RATTAN AS A CREATIVE AND INNOVATIVE EFFORT FOR STKIP SINGKAWANG STUDENTS
}

\author{
Rika Wahyuni ${ }^{1)}$, Ayu Indriani ${ }^{2)}$, Fransiska Ancis ${ }^{3)}$, Friska Willasari ${ }^{4)}$, Uley Lin ${ }^{5)}$ \\ 1) STKIP Singkawang, Singkawang, Indonesia \\ E-mail: rikawahyuni142@gmail.com \\ 5) National University of Kaohsiung, Kaohsiung, Taiwan \\ E-mail: uleylinn@gmail.com
}

\begin{abstract}
This study aims to develop students' interest and creativity in opening business opportunities that can increase experience, motivate them to develop innovations and creations. One of them is by using rattan. Rattan is a group of palms from the tribe (tribus) Calameae which has a climbing habitus, especially Calamus, Daemonorops, and Oncocalamus. Rattan grows wild in the forest or is planted intentionally. Rattan can be harvested at any time, with the attention that the bottom of the stem is not covered by petals, the leaves have dried, the thorns and petals have fallen off. Masaih rattan is easy to find in our area. Therefore we have the initiative to make handicrafts or items that are useful and value for sale. So, we STKIP Singkawang students innovate to make a study of rattan. In addition, to add to the attractiveness and selling value, we also add various forms so that buyers are more interested and for the price problem offered also according to the shape and size of the goods being produced. To market this product we sell it directly and through social media.
\end{abstract}

Keywords: crafts, creativity, rattan

\section{Introduction}

Indonesia is one of the developing countries with abundant natural resource potential. Therefore, Indonesia's export structure in the beginning mostly came from natural sources. Nowadays, so many handicrafts are made by machine power, so it is rare to find handicrafts. highly dedicated, and broadly advanced in doing a work (Kadjim, 2011).

Forests are a source of germplasm that has the potential to meet various human needs such as shelter, food and medicine. There are many benefits that can be taken directly from the forest, one of which is non-timber forest products such as game animals, food plants, honey, medicinal plants and also plants for traditional crafts such as weaving.

Rattan is a plant that grows in the tropics, so this plant can be found in Indonesia. Indonesian rattan has a dominant position in the world market, namely controlling $80 \%$ of the world's rattan raw material. Apart from Indonesia, rattan product plants can also be found in the Philippines, Thailand, Malaysia, India, Vietnam, Madagascar and Morocco. However, the greatest potential is currently in Indonesia. It can be seen that in Indonesia, rattan grows naturally and is spread in the regions of Java, Sumatra, Kalimantan, Sulawesi, and Irian Jaya. Crafts from rattan can be made into various useful items. If used wisely, rattan will become a more valuable item, so that it can provide business opportunities so that it can increase income 
with small capital and large profits. Rattan is a non-timber forest product which is widely used as a material for plaiting, for ropes and for making vegetables. Rattan has the potential to be developed as a trading material, both for domestic and export needs (Januminro, 2009).

Rattan that is ready to be harvested is rattan that has been cut, both in the forest and in the garden. The way to distinguish rattan that is ready to be harvested from rattan that is still young is usually the local people see directly from the color of the rattan leaves. The color of the rattan leaves that are ripe and cut usually begins to dry with a grayish, yellowish color and many leaves and thorns have fallen. The technique of taking rattan is by cutting the base of the rattan tree, pulling it until all parts of the rattan are visible, then rubbing the rattan on the trunk of the tree or wood and then cutting the ends of the rattan, the rattan is rolled.

In today's modern era, many people spend money on buying goods or products to complement their secondary needs. In fact, there are so many and easy things to find around us that can be used to make various creative, innovative, and economical selling products or crafts.

\section{Method}

Handicrafts made of rattan are used as household aids and home decorations. This type of research is descriptive. The research data is secondary data, namely the types of plants, plant parts and processing methods. The results of data interpretation will be described in a narrative about plant parts, plant types and processing and manufacturing methods.

\section{Results and Discussion}

The outputs of this activity include:

1. The manufacturing process is done by handmade

Products that are made by handmade are generally designed in great detail, so that the products produced are usually different and unique from one product to another.

2. This rattan can produce a variety of handicraft products

This rattan can be processed into several handicraft products, for example fruit rattan, rattan plates, takin and many others.

3. Handicraft products are priced in accordance with the quality of the products produced

These fruit rags are processed well, then they are produced using quality ingredients. So that the products produced are of high quality, this is what will affect the price of our products. The more complicated the work, the higher the price offered. 
Jurnal Terapan Manajemen dan Bisnis

Volume 6 Number 1 march 2020. Page 13-18

e-ISSN: 2477-5282 p-ISSN: 2599-3127

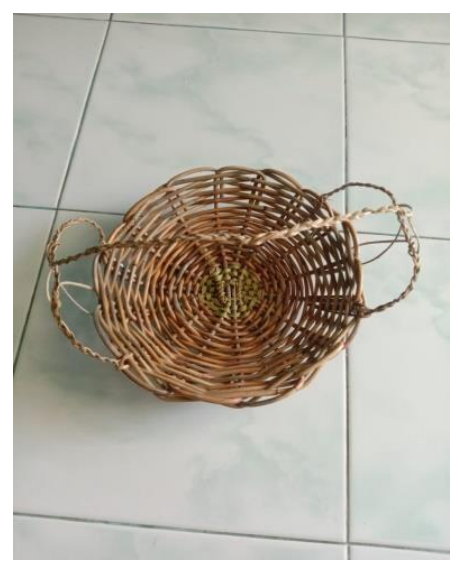

Picture 1

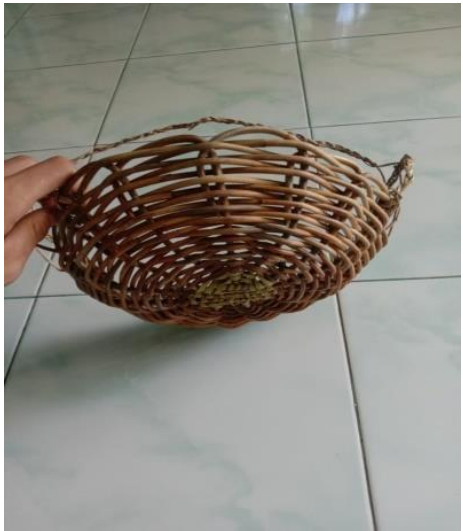

Picture 2

\section{SWOT analysis}

Market opportunities with bright and promising prospects previously rarely had competitors playing in this production. So that it opens up opportunities for us as business actors. We also conducted a SWOT analysis as follows: 
Table 2.2 SWOT analysis

\begin{tabular}{|l|l|l|}
\hline Strength & - & Can be produced by yourself \\
& - & Many people are interested \\
& - & Various creations don't make people bored \\
& - & Use ordinary items to become more attractive \\
& & items \\
\hline Weakness & - & There is no experience in making goods that are \\
& & more varied \\
& - & Complicated manufacturing process \\
& - & Many competitors from other materials, \\
\hline Opportunity & - & it is rare for producers to make handicrafts from \\
& & rattan \\
- & management is quite easy \\
- & get a lot of advantages \\
- & Have bright and promising prospects \\
- & Opportunity to dominate the market \\
\hline Threat & - & Difficulty in determining more unique and \\
& interesting shapes \\
- & The development of rattan handicrafts is \\
& considered ancient because many of the more \\
& modern crafts
\end{tabular}

Before carrying out this effort, we will prepare a design which is divided into stages as follows:

\section{Preparation Stage}

To start this business, there are several things that we have to prepare, namely:

\section{Business location}

The location for making rattan craft creations will be done in Singkawang, because this location is very strategic which will be used as a place of production as well as product marketing.

\section{Prepare rattan and the tools needed}

The material that needs to be prepared in making handicraft creations from rattan is rattan, because rattan is the main raw material in making this handicraft product. The tools needed must also be prepared to support the making of rattan craft creations.

\section{Production Stage}

If all the raw materials and tools have been prepared, then we are ready to carry out the next stage, namely the production stage, where we process rattan into crafts and crafts are the basic ingredients of making products, then created into various products.

\section{Promotion Stage}

Promotion can be done in several ways including direct promotion to prospective buyers, making sales stands at an exhibition, through social media and brochures.

\section{Marketing Stage}

We started marketing by directly offering products to prospective buyers, then we also marketed products through social media to expand marketing. 
Budget

Table 4.1.1 Summary of the Budget

\begin{tabular}{ccc} 
No & Type of Expenditure & Cost (Rp) \\
\hline 1. & Consumables & $\operatorname{Rp~4.025.000,00~}$ \\
2. & Others & $\underline{\operatorname{Rp~} 6.760 .000,00}$ \\
\hline & Total & $\underline{\operatorname{Rp~} 10.785 .000,00}$ \\
\end{tabular}

Schedule of activities

Table 4.1.2 Schedule of Activities

\begin{tabular}{|c|c|c|c|c|c|c|c|c|c|c|c|c|c|}
\hline \multirow{2}{*}{ No. } & \multirow{2}{*}{$\begin{array}{l}\text { Details of } \\
\text { activities }\end{array}$} & \multicolumn{4}{|c|}{ month -1} & \multicolumn{4}{|c|}{ month -2} & \multicolumn{4}{|c|}{ month -3} \\
\hline & & 1 & 2 & 3 & 4 & 1 & 2 & 3 & 4 & 1 & 2 & 3 & 4 \\
\hline 1. & $\begin{array}{l}\text { Proposal } \\
\text { creation }\end{array}$ & & & & & & & & & & & & \\
\hline 2. & $\begin{array}{l}\text { Procurement } \\
\text { of equipment }\end{array}$ & & & & & & & & & & & & \\
\hline 3. & $\begin{array}{l}\text { Procurement } \\
\text { of promotions }\end{array}$ & & & & & & & & & & & & \\
\hline 4. & Product trials & & & & & & & & & & & & \\
\hline 5. & $\begin{array}{l}\text { Product } \\
\text { manufacturing } \\
\text { process }\end{array}$ & & & & & & & & & & & & \\
\hline 6. & $\begin{array}{l}\text { Product } \\
\text { marketing }\end{array}$ & & & & & & & & & & & & \\
\hline
\end{tabular}

\section{Conclusions and recommendations}

Based on the results and discussion that has been described, the following conclusions can be drawn: rattan plants are used as handicrafts by the community. This study aims to develop students' interest and creativity in opening business opportunities that can increase experience, motivate them to develop innovations and creations. One of them is by using rattan. Rattan is a group of palms from the tribe (tribus) Calameae which has a climbing habitus, especially Calamus, Daemonorops, and Oncocalamus. Rattan grows wild in the forest or is planted intentionally. Rattan can be harvested at any time, with the attention that the bottom of the stem is not covered by petals, the leaves have dried, the thorns and petals have fallen off. Masaih rattan is easy to find in our area. Therefore we have the initiative to make handicrafts or items that are useful and value for sale.

The community needs to maintain local knowledge about rattan plants which are used as the basic material for making household aids and home decorations so that knowledge about rattan plants as the basic material for these tools is not forgotten. Efforts are needed to cultivate rattan plant species as material for household utensils and home decorations to ensure the sustainability of rattan plants to avoid extinction. Further research is needed to find out more about the use of rattan plants and local wisdom in the use of rattan plants as material for household aids and home decoration. 
Jurnal Terapan Manajemen dan Bisnis

Volume 6 Number 1 march 2020. Page 13-18

e-ISSN: 2477-5282 p-ISSN: 2599-3127

\section{References}

Aditya Sin Guiltia: http://shadowguiltia.blogspot.com/2017/02/analisis-swot-dalam-memulaiusaha.html. Februari 2017

Januminro.2009. Rotan Indonesia Edisi Revisi Menganyam Dunia Dengan Rotan.http:// Rotan $\% 20$ INDONESIA.

Simanjuntak, N., Idham, M., \& Ardian, H. (2016). Pemanfaatan Rotan Sebagai Bahan Kerajinan Anyaman di Desa Sedahan Jaya Kecamatan Sukadana Kabupaten Kayong Utara. Jurnal Hutan Lestari, 4(3). 